\title{
The Impact of Financial and Social Remittances in Perpetuating Migration (Albanian Migration Context)
}

\author{
Denisa Titili, PhD Cand. \\ Department of Social Sciences, University "Fan S. Noli" \\ xhafkadenisa@yahoo.com
}

\begin{abstract}
Since 1990 Albania has experienced massive external and international migration due to political, economical and social changes occurred in Albanian society. Albanian migration represents a variety of migratory experiences and a combination of different forms of migration (internal, external, temporary, permanent, etc) and destinations. Albania's contemporaneous mass emigration and internal migration over the short span of time since 1990 provides an excellent laboratory to study the inter links of these types of migration (King R, Skeldon R, \& Vullnetari J, 2008: 33). Migration and remittances have changed the social face of Albanian society. Based on the theoretical framework of De Haas (2010) that social remittances can further strengthen migration aspiration, the aim of this paper is to highlight the impact of financial and social remittances from emigrants to Greece in encouraging internal (rural to urban) and external ongoing migration. Data collection will be provided by in-depth interviews. This paper will base on case-histories of Albanian families with different migratory experience to show off how emigration to Greece has lead to a subsequent internal migration within Albania.
\end{abstract}

Keywords: internal and international migration, social remittances, cultural change

\section{Introduction}

The idea that migration often leads to more migration is anything but new. The migration literature has particularly highlighted the migration-facilitating role of migrant networks. This idea is that, once a critical number of migrants have settled at the destination, migration become self-perpetuating because it creates the social structure to sustain it (Massey et al 1993, de Haas 2010). As the costs and risks of migration are lowered by social and informational networks, once established migration streams tend to gain their own momentum.

People migrate for a variety of reasons related to desire for better income gain, demand to improve living conditions, employment opportunities, socio-economic inequality between areas, etc. Massey et al (1993) note that the conditions that initiate international movement may be quite different from those that perpetuate it across time and space. They refer to the impact of migrant networks which facilitate migratory movements by reducing the costs and risks of movement to the new destination. De Haas (2010) highlights that social remittances can further strengthen migration aspiration. Based on these theoretical frameworks the aim of this paper is to analyze the impact of financial and social remittances from Albanian emigrants to Greece on determining people's motivation and ability to migrate.

Internal and international migration is one of the most dynamic and specifying phenomenon of Albanian society after 1990. International migration acts as a source of development and hope for the future for internal migrants, but has also created an economic dependence for migrants' families. Social and financial remittances from international migrants are not only a livelihood for internal migrants, but also a mechanism that encourages internal (rural to urban) and external ongoing migration. 
The transition from a centrally planned economy to a free market economy, unemployment, the legacy of inefficient economic model from the former regime, the destruction of economic structures and political crisis of 1991 and 1997, were the main reasons that migration became the most satisfying solution to all major problems of Albanians.

By the end of 1990, about half a million Albanians have left the country in search of work and a better life. In 1995 the number of migrants is likely to have been between 450, 000 and 500, 000 (3/5 lived in Greece, 1/5 in Italy and 1/5 in Western Europe) (Albanian Housing and Population Census 2001). Besides emigration Albanian society has experienced the phenomenon of internal migration, expressed in massive urbanization of some areas and depopulation of the others.

The paper will first discuss the theoretical approaches focusing on the role of migrant networks and remittances on perpetuating migration phenomenon, while the second part of the paper will present two case-histories Albanian families which have experienced a complex migration trajectory including internal and international movements. Their life stories will be used as an empirical data to support the approaches mentioned before. Data derived from an ethnographic and participatory method, based on observation and in-depth interviews, which were useful in grasping families' migration trajectories.

\section{Network theory}

Migrant networks are sets of interpersonal ties $s$ that connect migrants, former migrants, and non migrants in origin and destination areas through ties of kinship, friendship, and shared community origin. They increase the likelihood of international movement because they lower the costs and risks of movement and increase the expected net returns to migration. Network connections constitute a form of social capital that people can draw upon to gain access to foreign employment. Once the number of migrants reaches a critical threshold, the expansion of networks reduces the costs and risks of movement, which causes the probability of migration to rise, which causes additional movement, which further expands the networks, and so on (Massey et al, 1993: 448-449).

\section{Cumulative causation theory}

In addition to the growth of networks and the development of migrant supporting institutions, international migration sustains itself in other ways that make additional movement progressively more likely over time, a process called cumulative causation (Massey et al, 1993: 451). Causation is cumulative in that each act of migration alters the social context within which subsequent migration decisions are made, typically in ways that make additional movement more likely. The main mechanism that ensures the continuity of migration, according to cumulative causation theory is the accumulation of social capital, which includes knowledge and information that members of a particular community have about migration through family members, relatives or friends who have already migrated (Massey 1999, Fussel \& Massey 2004). Any migratory movement creates a social capital about relatives or friends of migrants, which encourages migration, through which created more social capital that produces again migration (Fussel \& Massey, 2004: 152).

In support of the cumulative causation theory De Haas (2010) highlighted the impact of financial and social remittances, as one of the most defining dynamics of self-perpetuating nature of migration. Financial remittances increase income inequalities between communities and sending residents, encouraging in them the desire to migrate. This is supported by the social remittances (Levitt, 1998) which include the flow of ideas, behaviors, identities, social capital from host to sending communities that affect the social life of non migrants by making them desire to migrate.

\section{The impact of financial and social remittances}

Most studies focus on the impact of financial remittances in the economic development of the countries of origin. King et al, (2013) defines remittances as an important self-help mechanism for individuals and families, whose sacrifice of being away from their family, social group or their country is rewarded. Remittances contribute in increasing household income of migrants and improve their livelihoods. Immigrants through new financial resources also acquire a new social status. De Haas (2006) argues that migration phenomenon contributes to the creation of a new social stratification. Changes in cultural values and social stratification as well affect the extent to which economic and social benefits that come from migrants are distributed among their family, tribal group, etc. Based on a macroeconomic perspective financial remittances have played an important role in creating economic stability in Albania and managing trade deficit amounting to about $20 \%$ of GDP each 
year (Vullnetari 2007, Gëdeshi I \& Jorgoni E 2012). While from a micro level perspective financial remittances bring great economic benefits and social services for individuals and their families. The impact of financial remittances in improving economic situation of migrants' families creates the perception among non-migrant population that migration brings economic prosperity by promoting ongoing migration. Studies show that incomes from remittances are used to buy houses in the city by promoting rural to urban migration.

Besides financial remittances, researchers use the concept of social remittances to refer to the social and cultural impacts of migration to the country of origin as a result of ongoing contacts between migrants and the country of origin. Social remittances constitute a form of cultural diffusion that brings significant impacts on social and cultural values of sending communities (Levitt 1998, De Haas 2007, King et al, 2013).

Social remittance exchanges occur when migrants return to live in or visit their communities of origin, when non-migrants visit their migrant family members or through interchanges of letters, videos, phone calls. Social remittances travel through identifiable pathways; their source and destination are clear. Social remittance transmission occurs between individuals who know one another personally or who are connected to one another through mutual ties (Levitt, 1998: 936).

Researches differentiate between individual and collective social remittances; individuals communicate ideas and practices to each other in their roles as friends, family members, or neighbors. They also communicate in their capacity as members of organizations, hometown association, church (Levitt P \& Lamba-Nieves D, 2011: 2).

Vullnetari (2012) treats social remittances as important channels of social and cultural transformation in Albanian society. The impact of social remittances on developing communities of origin depends on a number of factors such as length of stay, country of emigration, the intensity of interactions between migrants and the host society, social and economic context in which migrants settle, etc. In Albanian migration context financial and social remittances have facilitated the process of internal migration and have encouraged an imagination or expectation of ongoing international migration as well.

\section{Albanian migration- general background}

Migration represents the most important social and economic phenomenon which has affected Albanian society after 1990. Over the last two decades migration phenomenon has been the center of economic, political, social and cultural transformation Albanian society has experienced. Albania's contemporaneous mass emigration and internal migration over the short span of time since 1990 provides an excellent laboratory to study the interlink between the two types of movement (King, Skeldon \& Vullnetari, 2008; 33).

Changes that characterized the Albanian society in the first phase of transition were accompanied by the removal of control of population movements, which accompanied by the massive shift of population from rural to urban areas. About 900,000 people moved from rural areas to urban centers as well as emigrated to other countries (INSTAT 2004: 10). The transition from a centralized economy to a free market economy, the high rate of unemployment, the destruction of economic structures and political crisis of 1991 and 1997, were the main reasons that emigration became more satisfactory solution for the major problems of Albanians. By the end of 1990, about half a million of Albanians have left the country in search of better life (Biberaj E, 2011: 37). Greece remains the main destination for Albanian emigrants from the south and southeast part of the country (IOM 2007, King \& Skeldon 2010, Vullnetari 2012).

Internal and international migration in Albanian context should be studied by an integrated migration theory which considers the two types of migration as interlinked processes. King \&

Skeldon (2010) consider international migration as an extension of internal migration. Both processes derive from similar causes related to inequalities in development between regions, countries, differences in employment, income, living conditions between cities, countries, etc.

Internal migration leads to international migration and vice versa.

Albanian migration is believed to have been commonly achieved in several phases. Many migrants have migrated internally before doing so internationally, others have initially migrated for a short time to Greece to finance the long-term migration 
to a further country. Others have moved from rural to urban areas after they have migrated abroad, using financial remittances to facilitate their movement from the village to the city (King 2005, Gëdeshi \& Jorgoni 2012, Vullnetari 2012).

Albanian migration trajectories are a combination of internal migration, international and return migration. The most common pattern in Albanian migration context is the emigration abroad, followed by a shift of the individual or family from rural to urban areas within the country.

From the perspective of internal migrants there is a significant correlation between the migration of people abroad and the movement of their family members from rural to urban centers. In most cases, internal migration is motivated and financially supported by the emigration of a member of the family.

\section{Case studies}

The first migration history belongs to Daniela and her family. Daniela is 35 years old, from Zëmblak village of Korça District. She got married in 1999 and emigrated to Greece with her husband one week after her wedding. They have a son and a daughter, who are born in Greece. Her husband comes from the same village and had emigrated in Thessaloniki (Greece) since he was 18 years old. He lived with his cousin (who had helped him establish and find work when he first arrived to Greece) in a small house and they used to share the rent of the house for several years. He continued to live in the same house with his wife for six months and then they (Daniela and her husband) moved to another house. After one year their son was born. For two years Daniela worked as a daily paid house cleaner, doing several works to Greek families. From 2002 she worked in a confectionery while her husband continued to work in constriction (he worked in construction since he first emigrated to Greece). They visited their village every year during summer time. Daniela's husband often sent money to his parents who lived in Zemblak village. They spent the money for daily needs and the rest of the money was saved. In 2005 Daniela's husband bought a shop in his ownership in Korça city with the money saved from their work in Greece. In 2006 their daughter was born. They continued to live and work in Greece until 2012 when Daniela and her family decided to come back to Albania. They moved to Korça city, and lived in a rented apartment. They invested to their estate, bought in 2005 in Korça city, by running a butcher shop. Since 2012 they both work in their family business and continue to live in a rented apartment in Korça city. They are planning to buy their own house in this city. During the interview Daniela tells many details from their live to Greece. She says "... we have sacrificed a lot during our stay in Greece and have helped many of our relatives and friends from our village who came to Greece next. We have helped them find work and even hold them in our house for a while until they established" (D. H, 34 years old).

The second history belongs to Koço (65 years old) and his family form Korça city. In 1990 he emigrated illegally in Athens (Greece) and found job as a decorator. He left behind his wife and his daughter and son. During the first year of his stay in Greece he tried to provide legal documents based on Greek ethnic origin of his grandfather. After getting the documents his family emigrated to Athens where they lived for 15 years. He continued to work as a decorator while his wife remained home looking after the children (they could afford life with his income). His daughter Heris finished the high school in Greece and then she attended a two year course for hairdresser. She married to Greece with an Albanian husband from Saranda (Albania) and worked as a hair dresser in Athens. They have two sons.

Koço's son returned in Albania in 2010 after he finished the high school in Greece. He decided to study in Tirana University (Tirana/ Albania). Two years later in 2012 Koço and his wife bought an apartment in Tirana city with money saved from work in Greece. They moved in Tirana and joined with their son who has just graduated and works as an interpreter of Greek language in Tirana city.

These case-histories of Albanian families represent a variation of migration patterns and different destinations. As it is mentioned above international migration may lead to internal movements. In both case- histories financial remittances and migrant networks play an important role in perpetuating migration phenomenon. 


\section{References}

Biberaj E. , (2011), Shqipëria në tranzicion- Rruga e vështirë drejt demokracisë 1990- 2010, Instituti i Studimeve Ndërkomëtare, Tiranë AISS

De Haas H. , (2010), The Internal Dynamics of Migration Processes: A Theoretical Inquiry, Journal of Ethnic and Migration Studies 36(10): 1587 - 1617

De Haas H. , (2006), The social and cultural impacts of international migration on Moroccan, communities: a review, Morocco \& Netherlands: Society, Economy, Culture, pp. 124-138

Fussel \& Massey. , (2004), The Limits to Cumulative Causation: International Migration From Mexican Urban Areas, Demography, Volume 41, Number 1, pp. 151-171

Gedeshi I \& Jorgoni E, (2012), Social impact of emigration and rural- urban migration in Central and Eastern Europe (Albania), European Commission

INSTAT (2004), Migracioni në Shqiperi, Regjistrimi i popullsisë dhe i banesave 2001

IOM, (2007), The Republic of Albania Migration Profile

King R. , Skeldon R \& Vullnetari J, (2008), Internal and international migration: Bridging the theoretical divide, University of Sussex

King R. , Skeldon R. , (2010), 'Mind the Gap!' Integrating Approaches to Internal and International Migration, Journal of Ethnic and Migration Studies Vol. 36, No. 10, pp. 1619-1646

King, R. , \& Vullnetari, J. (2009). The intersections of gender and generations in Albanian migration, remittances and transnational care, Journal Compilation, Swedish Society for Anthropology and Geography, Vol. 91, 19-38

King et al. , (2013),

Levitt P. , (1998), Social Remittances; Migration Driven Local-Level Forms of Cultural Diffusion, International migration Review, Vol. 32, No. 4, pp. 926-948

Levitt P \& Lamba-Nieves D. , (2011), Social remittances revisited, Journal of Ethics and Migration Studies, Vol. 38, No. 1, 1-22

Massey et al. , (1993), Theories of international migration: A review and appraisal, Population and Development Review, Vol. 19, No. 3, 431-466

Vullnetari J. , ( 2007), Albanian migration and development: State of the art review, ISIMICOE

Working Paper, No. 18

Vullnetari J. , (2012), Albania on move- links between internal and international migration, Amsterdam University Press 